\title{
PENEGAKAN HUKUM DALAM PENYIDIKAN TINDAK PIDANA PENYALAHGUNAAN NARKOTIKA
}

\author{
Agus Setiawan \\ Kepolisian Resort Semarang \\ agusetiawn23@gmail.com
}

\begin{abstract}
The development of narcotic crime over time shows an increasing trend, so that enforcement should be improved. In law enforcement the narcotic crime, the police are law enforcement officers act as investigators. The problems discussed in this research is how the law enforcement narcotic crime in the jurisdiction of Police Semarang, the factors that affect law enforcement narcotic crime and any obstacles that arise in law enforcement narcotic crime in the jurisdiction of Police Semarang and effort overcome. The method used in this research is juridical sociological. The data used are primary data and secondary data. The method of data collection is done through field studies and literature, while the method of data analysis using qualitative analysis. The results show, that law enforcement narcotic crime at the stage of investigation carried out under the provisions of the Criminal Procedure Code. Factors that affect law enforcement narcotic crime is a factor of legislation, law enforcement apparatus, means or facility factors, community factors, and cultural factors. The obstacles that arise in law enforcement narcotic crime consist of internal resistance and external barriers.
\end{abstract}

Keyword: Investigation, Investigator Civil Servant, Violation.

\section{A. PENDAhUluan}

Narkotika yang disalahgunakan atau digunakan tidak sesuai dengan standar pengobatan akan menimbulkan akibat yang sangat merugikan perorangan maupun masyarakat, bahkan dapat menimbulkan bahaya yang lebih besar bagi kehidupan dan nilai-nilai budaya bangsa yang pada akhirnya akan dapat melemahkan ketahanan nasional. 
Penyalahgunaan narkotka di Indonesia sudah menjadi semacam way of life, khususnya di kalangan artis, yuppies (young urban professionals), kelas menengah ke atas dan lainnya. ${ }^{1}$ Praktek penyalahgunaan narkotika tidak hanya terjadi di perkotaan saja melainkan sudah merambah ke pedesaan dan pada semua golongan masyarakat baik kaya, miskin, tua, muda, bahkan tidak jarang terdapat aparat penegak hukum yang terjerumus dalam penyalahgunaan narkotika. Penyalahgunaangunaan narkotika merupakan suatu perbuatan tindak pidana. Menurut Moeljatno, perbuatan pidana merupakan sesuatu perbuatan yang dilarang oleh suatu peraturan hukum dan juga disertai suatu sanksi pidana tertentu. ${ }^{2}$

Indonesia merupakan negara yang berasaskan hukum, dimana secara teoritis sifat dari hukum adalah universal, yang berarati penanganan dan perundangannya berlakusama terhadap semua warga masyarkat. ${ }^{3}$ Sebagai negara hukum Indonesia memilki produk-produk hukum yang dimaksudkan untuk mengatur segala tindakan seluruh masyarakat,salah satunya adalah hukum pidana. Terkait dengan tindak pidana narkotika, Indonesia telah mempunyai produk hukum yang mengaturnya sendiri yatu Undang-Undang Nomor 35 Tahun 2009 tentang Narkotika. Undang-undang tersebut mengatur perbuatan yang dilarang dan dipidana beserta sanksi-sanksi dijatuhkan terhadap pelaku tindak pidana.

Terkait dengan penanganan tindak pidana narkotika, Polri merupakan aparat penegak hukum yang berperan sebagai penyidik. Dalam pelaksanaan tugasnya sebagai penyidik, Polri mempunyai wewenang yang diatur dalam Pasal 16 ayat (1) Undang-Undang Nomor

1 Soedjono Dirdjosisworo, 2006, Narkoba dan Peradlannya di Indonesia, O.C Kaligis\&Assocates, Jakarta, hal.249.

2 Moeljatno, 2008, Asas-asas Hukum Pidana, Rineka Cipta, Jakarta, hal. 54.

3 Wirjono Prodjodikoro, 2003, Tindak-Tindak Pidana Tertentu di Indonesia, PT. Refika Aditama, Bandung, hal. 1. 
2 Tahun 2002 tentang Kepolisian Negara Republik Indonesia.

Dilihat dari segi yuridisnya, tindakan pertama yang dilakukan oleh kepolisian adalah awal untuk dilakukannya penyidikan, setelah sebelumnya diketahui akan adanya atau diduga terjadi suatu tindak pidana, sehingga dapat dikatakan bahwa tindakan kepolisian tersebut merupakan penyelenggaraan hukum yang bersifat represif, yang pada prinsipnya harus didasarkan pada peraturan perundang-undangan yang berlaku, seperti KUHP dan ketentuan Hukum Acara Pidana.

Penyidikan sebagai tindakan awal penyelesaian perkara pidana memiliki peranan penting dalam menentukan posisi suatu perkara pidana. KUHAP memberikan pengertian bahwa penyidikan adalah serangkaian tindakan penyidik dalam hal dan menurut cara yang diatur dalam undang-undang ini untuk mencari serta mengumpulkan bukti yang dengan bukti itu membuat terang tentang tindak pidana yang terjadi dan guna menemukan tersangkanya. Hasil penyidikan akan menjadi bukti awal sebagai dasar diadakannya penuntutan membuat proses penyidikan menjadi suatu proses hukum yang patut dicermati.

Perkembangan tindak pidana narkotika dari waktu ke waktu menunjukkan kecenderungan yang semakin meningkat, bahkan kasuskasus yang terungkap oleh jajaran Kepolisian RI hanyalah merupakan fenomena gunung es, yang hanya sebagian kecil saja yang tampak di permukaan sedangkan kedalamannya tidak terukur. Tindak pidana narkotika tidak lagi dilakukan secara perseorangan, melainkan melibatkan banyak orang yang secara bersama-sama, bahkan merupakan satu sindikat yang terorganisasi dengan jaringan yang luas yang bekerja secara rapi dan sangat rahasia baik di tingkat nasional maupun maupun internasional.

Di Indonesia saat ini angka penyalahgunaan narkoba telah mencapai titik yang mengkhawatirkan, karena pada saat sekitar awal 
tahun 1990-an masalah narkotika masih belum popular dan oleh jaringan pengedar hanya dijadikan sebagai negara transit saja, belakangan ini telah dijadikan sebagai negara tujuan atau pangsa pasar dan bahkan dinyatakan sebagai negara produsen/pengekspor narkotika terbesar di dunia. ${ }^{4}$

\section{B. METODE PENELITIAN}

Metode pendekatan yang digunakan dalam penelitian ini adalah yuridis sosiologis, yaitu mempelajari dan meneliti hubungan timbal balik antara hukum dengan lembaga-lembaga sosial yang lain. Hukum tidak dikonsepsikan sebagai suatu gejala normatif yang mandiri, tetapi sebagai suatu institusi sosial yang dikaitkan secara riil dengan variabelvariabel sosial. Hukum yang secara empiris merupakan gejala masyarakat, di satu pihak dapat dipelajari sebagai suatu variabel penyebab (independent variable) yang menimbulkan akibat-akibat pada berbagai segi kehidupan sosial. Di samping itu, hukum dapat juga dipelajari sebagai variabel akibat (dependent variable) yang timbul sebagai hasil akhir dari berbagai kekuatan dalam proses sosial. ${ }^{5}$ Dalam penelitian ini, pada awalnya yang diteliti adalah data sekunder untuk kemudian dilanjutkan dengan penelitian terhadap data primer di lapangan atau terhadap prakteknya. Permasalahan yang dibahas dalam hal ini adalah penegakan hukum tindak pidana narkotika di wilayah hukum Polres Semarang.

\section{HASIL PENELITIAN DAN PEMBAHASAN}

\section{Penegakan Hukum dalam penyidikan penyalahgunaan narkotika}

Penegakan hukum pada tingkat penyidikan terhadap tindak pidana narkotika dilakukan melalui tahapan tahapan sebagai berikut :

\footnotetext{
4 Tempointeraktif, Indonesia Kini Jadi Pengekspor Narkoba, (http://www.tempo.co.id, diakses 25 November 2016).

${ }^{5}$ Ronny Hanitijo Soemitro, 1988, Metode Penelitian Hukum dan Jurimetri, Ghalia Indonesia, Jakarta, 1988, hal. 34.
} 
a. Laporan Polisi

Laporan polisi adalah laporan tertulis yang dibuat oleh anggota polisi tentang adanya suatu peristiwa yang diduga terdapat pidananya, baik yang ditemukan sendiri maupun melalui pemberitahuan yang disampaikan oleh seseorang karena hak atau kewajiban berdasakan undang undang (Pasal 1 ayat (24) KUHAP). Pada tindak pidana narkotika yang terjadi di Polres Semarang ditemukan sendiri oleh anggota Polri setelah melakukan penyelidikan secara tertutup. Penyelidikan secara tertutup dilakukan apabila suatu tindak pidana ini belum terungkap siapa pelaku tindak pidana dan tidak memungkinkan dilakukan secara terbuka. Yaitu dengan cara undercover dan survailen.

Mengenai penyelidikan, UU No. 35 Tahun 2009 tidak mengatur secara khusus, sehingga pelaksanaan penyelidikan mengacu pada KUHAP. Menurut Pasal 5 KUHAP, penyelidik mempunyai wewenang sebagai berikut :

1. menerima laporan atau pengaduan dari seorang tentang adanya tindak pidana;

2. mencari keterangan dan barang bukti;

3. menyuruh berhenti seorang yang dicurigai dan menanyakan serta memeriksa tanda pengenal diri;

4. mengadakan tindakan lain menurut hukum yang bertanggung jawab.

Selanjutnya atas perintah penyidik, penyelidik dapat melakukan tindakan berupa :

1. penangkapan, larangan meninggalkan tempat, penggeledahan dan penyitaan;

2. pemeriksaan dan penyitaan surat; 
3. mengambil sidik jari dan memotret seorang; 4. membawa dan menghadapkan seorang pada penyidik.

Berdasarkan ketentuan Pasal 5 KUHAP tersebut, maka tindakan penyelidik yang melakukan tindakan penangkapan dan penggeledahan terhadap tersangka dapat dibenarkan dan sudah sesuai dengan kewenangannya. Hal ini sesuai dengan ketentuan Pasal 16 KUHAP yang menyatakan bahwa untuk kepentingan penyelidikan, penyelidik atas perintah penyidik berwenang melakukan penangkapan.

b. Pemanggilan

Dalam hal pemanggilan tersangka atau saksi yang berwenang mengeluarkan surat panggilan adalah kepala kesatuan atau pejabat yang ditunjuk selaku penyidik/ penyidik pembantu (Pasal 112 ayat (1) KUHAP). Pemanggilan merupakan kegiatan penyidik di tingkat penyidikan untuk memenuhi bagaimana suatu tindak pidana itu terjadi sehingga diperlukan adanya keterangan para saksi, juga kepada pelaku tindak pidana untuk bisa mengetahui peran pelaku dalam melakukan tindak pidana.

Dari hasil penelitian dalam tindak pidana narkotika, pemanggilan terhadap para saksi ada yang tanpa surat panggilan, dan ada yang menggunakan surat pemanggilan resmi. Bagi anggota Polri yang telah melakukan penangkapan terhadap tersangka, tidak dilakukan panggilan resmi, tetapi bagi saksi orang sipil/umum, dilakukan pemanggilan secara resmi dan segera dibuatkan berita acaranya.

c. Penggeledahan

Tindakan lain yang dilakukan oleh penyidik dalam rangka penyidikan adalah penggeledahan yang dibedakan menjadi dua, 
yaitu :

1) Penggeledahan rumah

Adalah tindakan penyidik untuk mengadakan pemeriksaan tempat tinggal dan tempat tertutup lain untuk melakukan tindakan pemeriksaan dan atau penyitaan dan atau penangkapan dalam hal dan menurut cara yang diatur dalam Undang-Undang. Pada saat akan memasuki rumah harus disaksikan oleh Kepala Desa atau ketua lingkungan dengan dua orang saksi, dalam hal tersangka atau penghuni menolak atau tidak hadir.

2) Penggeledahan badan/pakaian

Adalah tindakan penyidik untuk mengadakan pemeriksaan badan dan atau pakaian tersangka untuk mencari benda yang diduga keras ada pada badannya atau dibawanya serta untuk disita. Apabila dalam penggeledahan diketemukan sesuatu yang diperlukan sebagai bukti, maka dapat dilakukan penyitaan, yaitu serangkaian tindakan penyidik untuk mengambil alih dan atau menyimpan di bawah pengusaannya benda bergerak atau tidak bergerak, berwujud atau tidak berwujud untuk kepentingan dalam penyidikan, penuntutan dan peradilan (Pasal 1 butir 16 KUHAP).

Kewenangan penyidik dalam melakukan penggeledahan diatur dalam Pasal 75 huruf e UU Nomor 35 Tahun 2009 yang menyatakan, bahwa penyidik berwenang memeriksa, menggeledah, dan menyita barang bukti tindak pidana dalam penyalahgunaan dan peredaran gelap Narkotika dan Prekursor Narkotika. Selain itu dalam pelaksanaan penggeledahan berpedoman pada Pasal $32 \mathrm{~s} / \mathrm{d}$ Pasal 37 KUHAP. Menurut Pasal 32 KUHAP, untuk kepentingan penyidikan, penyidik dapat melakukan penggeledahan rumah atau 
penggeledahan pakaian atau penggeledahan badan menurut tata cara yang ditentukan dalam undang-undang.

Adapun mengenai penggledahan badan diatur dalam Pasal 37 KUHAP yang menyatakan bahwa pada waktu menangkap tersangka, penyelidik hanya berwenang menggeledah pakaian termasuk benda yang dibawanya serta, apabila terdapat dugaan keras dengan alasan yang cukup bahwa pada tersangka tersebut terdapat benda yang dapat disita. Pada waktu menangkap tersangka atau dalam hal tersangka, penyidik berwenang menggeledah pakaian dan atau menggeledah badan tersangka.

d. Penangkapan tersangka

Seorang penyidik berwenang untuk melakukan penangkapan akan tetapi harus dengan perintah penyidik, kecuali dalam hal tertangkap tangan (Pasal $16 \mathrm{KUHAP}$ ). Adapun pelaksanaan tugas penangkapan dilaksanakan oleh petugas Polri dengan disertai surat tugas serta memberikan kepada tersangka surat perintah penangkapan yang mencantumkan identitas tersangka dan menyebutkan alasan penangkapan serta uraian singkat kejahatan yang disangkakan dan tempat ia diperiksa. Tembusan surat perintah penangkapannya harus diberikan kepada keluarganya segera setelah penangkapan dilakukan. Sedang dalam hal tertangkap tangan tidak perlu memakai surat perintah (Pasal 18 KUHAP).

Ketentuan mengenai lamanya waktu penangkapan diatur dalam Pasal 19 ayat (1) KUHAP yang menyatakan, bahwa penangkapan dapat dilakukan untuk paling lama satu hari. Akan tetapi berdasarkan ketentuan Pasal 76 Undang-Undang Nomor35 tahun 2009 tentang Narkotika menentukan, bahwa pelaksanaan kewenangan penangkapan dilakukan paling lama $3 \times 24$ (tiga kali 
dua puluh empat) jam terhitung sejak surat penangkapan diterima penyidik dan dapat diperpanjang paling lama $3 \times 24$ (tiga kali dua puluh empat) jam. Dengan demikian pada tindak pidana narkotika, penangkapan bisa berlaku paling lama 3 × 24 jam.

e. Penahanan terhadap tersangka

Penahanan terhadap tersangka dilakukan dengan surat perintah penahanan, dan segera setelah dilakukan penahanan dibuatkan berita acara penahanan. Penahanan terhadap tersangka dilakukan untuk kepentingan pemeriksaan. Hasil penelitian di Polres Semarang, terhadap tersangka pelaku tindak pidana narkotika, tersangka ditempatkan di ruang tahanan Polres Semarang. Lamanya waktu penahanan adalah 20 hari sebagaimana diatur dalam Pasal 24 ayat (1) yang menyatakan bahwa perintah penahanan yang diberikan oleh penyidik hanya berlaku paling lama dua puluh hari. Jangka waktu tersebut dapat diperpanjang oleh penuntut umum yang berwenang untuk paling lama empat puluh hari.

Alasan dilakukannya penahanan terhadap tersangka adalah sebagaimana ketentuan Pasal 21 ayat (1) KUHAP, yang menyatakan bahwa perintah penahanan atau penahanan lanjutan dilakukan terhadap seorang tersangka atau terdakwa yang diduga keras melakukan tindak pidana berdasarkan bukti yang cukup, dalam hal adanya keadaan yang menimbulkan kekhawatiran bahwa tersangka atau terdakwa akan melarikan diri, merusak atau menghilangkan barang bukti dan atau mengulangi tindak pidana. Alasan tersebut merupakan syarat subjektif dikenakannya tindakan penahanan terhadap tersangka dilihat dari segi keperluan. Adapun syarat objektif dikenakan tindakan penahanan adalah sebagaimana ketentuan Pasal 21 ayat (4) KUHAP yaitu tindak pidana yang 
diancam dengan pidana penjara lima tahun atau lebih; dan tindak pidana sebagaimana dimaksud dalam Pasal 282 ayat (3), Pasal 296, Pasal 335 ayat (1), Pasal 351 ayat (1), Pasal 353 ayat (1), Pasal 372, Pasal 378, Pasal 379 a, Pasal 453, Pasal 454, Pasal 455, Pasal 459, Pasal 480 dan Pasal 506 Kitab Undang-undang Hukum Pidana, Pasal 25 dan Pasal 26 Rechtenordonnantie (pelanggaran terhadap ordonansi Bea dan Cukai, terakhir diubah dengan Staatsblad Tahun 1931 Nomor 471), Pasal 1, Pasal 2 dan Pasal 4 Undang-undang Tindak Pidana Imigrasi (Undang-undang Nomor 8 Drt. Tahun 1955, Lembaran Negara Tahun 1955 Nomor 8), Pasal 36 ayat (7), Pasal 41, Pasal 42, Pasal 43, Pasal 47, dan Pasal 48 Undang-Undang Nomor 9 Tahun 1976 tentang Narkotika (Lembaran Negara Tahun 1976 Nomor 37, Tambähan Lembaran Negara Nomor 3086). Hal ini sebagaimana dikemukakan oleh Bapak Bambang Hidayat yang menyatakan, bahwa penahanan dilakukan untuk kepentingan pemeriksaan dan agar tersangka tidak melarikan diri.

Dengan demikian, pelaksanaan penahanan terhadap tersangka pelaku tindak pidana narkotika di Polres Semarang telah sesuai dengan ketentuan KUHAP dan Undang-Undang Nomor 35 Tahun 2009 tentang Narkotika.

f. Penyitaan barang bukti

Hasil penelitian di Polres Semarang dilakukan penyitaan barang bukti dalam tindak pidana narkotika. Dalam contoh kasus, barang bukti yang disita berupa narkotika yang dimiliki oleh pelaku, handphone yang digunakan oleh pelaku untuk berkomunikasi dengan penjual narkotika dan urine dari tersangka.

Untuk melakukan penyitaan berdasarkan surat perintah penyitaan dengan meminta persetujuan ketua pengadilan setempat. Akan tetapi dalam banyak kasus yang terjadi, penyitaan 
dilakukan ketika tertangkap tangan, sehingga terkadang dilakukan tanpa harus menunggu persetujuan dari ketua pengadilan setempat. Dalam hal tertangkap tangan, penyitaan dilakukan tanpa surat perintah ataupun surat penetapan pengadilan, akan tetapi setelah dilakukan tindakan penyitaan segera dibuatkan dimohonkan surat penetapan pengadilan berikut berita acaranya. Dengan demikian proses penyitaan dalam penyidikan tindak pidana narkotika telah sesuai dengan ketentuan KUHAP.

g. Pemeriksaan

Pemeriksaan merupakan kegiatan untuk mendapatkan keterangan, kejelasan dan keidentitasan tersangka atau saksi atau barang bukti (Pasal 183 dan Pasal 184 KUHAP) maupun unsur unsur tindak pidana yang telah terjadi, sehingga kedudukan atau peranan seseorang maupun barang bukti didalam tindak pidana tersebut menjadi jelas dan dituangkan dalam berita acara, pemeriksaan dan yang berwenang adalah penyidik atau penyidik pembantu.

Tata cara pemeriksaan yang dilakukan oleh penyidik sesuai dengan yang dikemukakan oleh M. Yahya Harahap, yaitu sebagai berikut : 6

1. Masing-masing saksi diperiksa sendiri-sendiri terpisah antara saksi yang satu dengan saksi yang lain misalnya secara bergiliran. Hal ini dilakukan untuk menjaga agar keterangan yang diberikan oleh saksi bersifat obyektif.

2. Pemeriksaan dilakukan dengan jalan wawancara dengan mengajukan pertanyaan-pertanyaan kepada saksi tentang apa yang dilihat, didengar dan diketahui sendiri tentang peristiwa

${ }^{6}$ M. Yahya Harahap, Op.Cit., halaman 136. 
tersebut. Berdasarkan keterangan-keterangan tersebut dapat diperoleh petunjuk-petunjuk yang sangat penting.

3. Pada waktu sebelum pemeriksaan terhadap saksi, penyidik atau penyidik pembantu akan menanyakan keadaan saksi, apakah pada waktu dilakukan pemeriksaan dalam keadaan sehat. Penyidik atau penyidik pembantu selesai memeriksa juga menanyakan tentang kemungkinan jawaban saksi mendapat tekanan atau pengaruh dari pihak luar. Setelah selesai melakukan pemeriksaan terhadap para saksi maka penyidik atau penyidik pembantu membuat berita acara pemeriksaan.

Dalam pemeriksaan pelaku tindak pidana yang masih dalam proses penyidikan harus dianggap sebagai tersangka, walaupun sudah ada petunjuk-petunjuk yang sudah terang. Adapun cara penyidik atau penyidik pembantu dalam melakukan pemeriksaan terhadap tersangka adalah sebagai berikut : ${ }^{7}$

1. Pemeriksaan harus dilakukan secepat mungkin sebab bila terlalu lama jangka waktunya, ingatan terhadap peristiwa yang lalu menjadi kabur dan tersangka dikuatirkan sudah mempersiapkan siasat untuk mungkir.

2. Pemeriksaan dengan jalan melakukan wawancara, dengan banyak mengajukan pertanyaan-pertanyaan dengan sebelumnya membuat persiapan-persiapan yang cukup yaitu tentang gambaran TKP dan kesimpulan-kesimpulan dari pernyataan-pernyataan yang diperoleh dari keteranganketerangan para saksi dan barang bukti yang ada.

Titik pangkal pemeriksaan dihadapan penyidik adalah tersangka. Dari tersangka diperoleh keterangan tentang peristiwa pidana yang sedang diperiksa. Akan tetapi, sekalipun tersangka

7 Wawancara dengan Angudi Sambodo selaku Kasat Narkoba Polres Semarang, tanggal 6 Februari 2017 di Polres Semarang. 
menjadi titik tolak pemeriksaan, terhadapnya harus diberlakukan asas akusatoir, yaitu asas yang menempatkan tersangka atau terdakwa sebagai subyek dalam pemeriksaan perkara pidana. Tersangka harus ditempatkan pada kedudukan manusia yang memiliki harkat martabat. Dia harus dinilai sebgai subjek, bukan sebgai objek. Yang diperiksa bukan manusia tersangka. Perbuatan tindak pidana yang dilakukannyalah yang mejadi objek pemeriksaan. Ke arah kesalahan tindak pidana yang dilakukan pemeriskaan ditujukan. Tersangka harus dianggap tidak bersalah, sesuai dengan prinsp hukum "praduga tak bersalah" sampai diperoleh putusan pengadilan yang telah berkekuatan tetap.

Penyidik atau penyidik pembantu sebelum melakukan pemeriksaan terhadap tersangka, ia harus menanyakan kepada tersangka tentang perlunya tersangka didampingi penasehat hukum pada waktu menjalani proses penyidikan. Bantuan ini merupakan suatu perwujudan daripada perlindungan hak asasi manusia.

Setelah pemeriksaan terhadap tersangka dianggap cukup, penyidik atau penyidik pembantu menanyakan kepada tersangka apakah perlu menambah keterangan dan apakah ingin mengajukan saksi yang meringankan untuk diperiksa. Apabila semuanya telah selesai maka hasil dari pemeriksaan tersebut dibuat berita acara pemeriksaannya.

h. Pemeriksaan barang bukti di laboratorium

Pemeriksaan barang bukti dilakukan di Laboratorium Forensik Semarang atau BPOM Semarang. Pemeriksaan barang bukti di laboratorium bertujuan untuk menjelaskan secara resmi apakah barang bukti narkotika yang dimiliki oleh tersangka mengandung narkotika atau tidak sebagaimana diatur dalam 
daftar Lampiran UU Nomor 35 Tahun 2009 tentang Narkotika.

i. Penyelesaian berkas perkara

Waktu yang dimiliki oleh penyidik dalam menyelesaikan berkas perkara adalah selama 60 hari sesuai dengan lamanya masa penahanan terhadap tersangka. Selama waktu tersebut penyidik harus bisa menyelesaikan pemberkasan dan telah melimpahkan tersangka dan barang bukti kepada Jaksa Penuntut Umum. Setelah 60 hari, apabila penyidik belum bisa menyelesaikan berkas perkara, maka penyidik harus mengeluarkan tersangka dari tahanan demi hukum, hal ini sebagaimana diatur dalam Pasal 24 KUHAP.

Setelah berkas perkara selesai disusun sebagaimana ketentuan yang telah ditentukan, maka berkas perkara tersebut di serahkan kepada Jaksa. Penyerahan berkas perkara terdiri dari 2 tahap, yaitu penyerahan berkas perkara untuk diteliti oleh Jaksa peneliti, penyerahan ini yang biasa disebut tahap pertama, dan penyerahan tahap dua yaitu pelimpahan tanggung jawab atas tersangka dan barang bukti.

Berdasarkan hasil wawancara dengan Bapak Angudi Sambodo, untuk menentukan apakah tersangka adalah pengguna narkotika dilakukan dengan melakukan tes urine ataupun tes darah terhadap pelaku. Kemudian untuk memastikan apakah barang bukti merupakan narkotika atau tidak juga harus dilakukan pemeriksaan. Waktu yang dibutuhkan untuk pemeriksaan tes urine maupun barang bukti memerlukan waktu yang lama. Untuk itulah dalam tindak pidana narkotika, waktu penangkapan lebih lama dari ketentuan KUHAP yang hanya berlaku $1 \times 4$ jam, tetapi menjadi $3 \times 24$ jam. Dengan waktu tersebut, penyidik mempunyai waktu yang cukup untuk melakukan pemeriksaan. ${ }^{8}$

${ }^{8}$ Wawancara dengan Angudi Sambodo selaku Kasat Narkoba Polres Semarang, 
Hasil penelitian di Polres Semarang memberikan gambaran bahwa dalam penegakan hukum terhadap tindak pidana selalu dilakukan pengembangan kasus. Hal ini dikarenakan tersangka dalam melakukan tindak pidana pasti berhubungan dengan pihak lain (pelaku tindak pidana narkotika yang lain), karena tindak pidana narkotika sudah dipastikan membentuk jaringan. Meskipun pada akhirnya pengembangan kasus tidak berhasil, namun terhadap tersangka tetap dilakukan proses hukum sesuai ketentuan yang berlaku.

Dalam upaya penegakan hukum terhadap tindak pidana narkotika, Polres Semarang (pada tingkat penyidikan) bekerjasama dengan BNP Jawa Tengah. Hal ini sejalan dengan ketentuan Pasal 84 Undang-Undang Nomor 35 Tahun 2009 yang menyatakan bahwa dalam melakukan penyidikan terhadap penyalahgunaan dan peredaran gelap narkotika dan prekursor narkotika, penyidik Kepolisian Negara Republik Indonesia memberitahukan secara tertulis dimulainya penyidikan kepada penyidik BNN begitu pula sebaliknya.

Penyidik juga berkoordinasi dengan pihak Kejaksaan Negeri Ambarawa dalam melakukan proses penyidikan tindak pidana narkotika. Koordinasi sering dilakukan pada saat gelar perkara awal. Koordinasi antara penyidik dengan kejaksaan telah diatur dalam pasalpasal KUHAP sebagai berikut :

1. Pasal 109 ayat (1) KUHAP, mengenai pemberitahuan dimulainya penyidikan

2. Pasal 109 ayat (2) KUHAP, mengenai penghentian penyidikan

3. Pasal 140 ayat (2) KUHAP, penyidik menghentikan penuntutan

4. Pasal 110 ayat (1) KUHAP, penyerahan berkas perkara hasil penyidikan 
5. Pasal 110 ayat (2) dan (3) KUHAP, penyidikan lanjutan berdasarkan petunjuk penuntut umum dalam berkas dinyatakan kurang lengkap

6. Pasal 143 ayat (4), penuntut umum memberikan surat turunan surat pelimpahan perkara, surat dakwaan kepada penyidik

7. Pasal 144 ayat (3) KUHAP, penuntut mengubah surat dakwaan dengan memberikan turunan perubahan surat dakwaan kepada penyidik.

\section{Solusinya Penyidik PPNS dalam melaksanakan penyidikan tindak pidana Keimigrasian}

Upaya penegakan hukum tindak pidana narkotika tidak selamanya berjalan mulus, karena ada hambatan-hambatan yang kadang-kadang muncul. Hambatan-hambatan tersebut dapat berasal dari dalam (internal) dan eksternal (dari luar). Adapun hambatanhambatan tersebut adalah $:^{9}$

1. Hambatan dari dalam (internal)

Hambatan internal adalah hambatan yang berasal dari dalam, yaitu dari pihak Polres Semarang. Adapun hambatan tersebut adalah kurangnya jumlah personel di sat Narkoba Polres Semarang. Sebagaimana diketahui, bahwa jumlah personel di Sat Narkoba Polres Semarang sangat sedikit, yaitu ada 8 orang. Dengan jumlah penyidik yang hanya 8 orang, sedangkan jumlah kasus narkotika mencapai puluhan kasus, akan membuat kasus-kasus yang ditangani menjadi menumpuk. Hal ini sangat mengambat kinerja penyidik dalam penyelesaian perkara.

2. Hambatan dari luar (eksternal)

a. Peredaran gelap narkotika menggunakan cara putus jaringan Kemudahan akses teknologi yang ada saat ini

${ }^{9}$ Wawancara dengan Angudi Sambodo selaku Kasat Narkoba Polres Semarang, tanggal 6 Februari 2017 di Polres Semarang. 
memudahkan terjadinya transaksi jual beli tanpa harus bertatap muka satu sama lain. Pembeli dan penjual tidak saling kenal (penjual tidak tahu siapa yang membeli narkotika, pembeli tidak tahu siapa penjualnya dan siapa yang mengirimkannya karena hanya berkomunikasi melalui HP ataupun internet. Dengan sistem jaringan terputus ini, penyidik kesulitan untuk melakukan pengembangan kasus.

b. Tersangka menghilangkan barang bukti

Tersangka tindak pidana narkotika sangat pandai berkelit saat akan dilakukan penangkapan. Barang bukti tindak pidana narkotika sangat mudah untuk dihilangkan mengingat bentuknya yang kecil atau serbuk. Sebagai contoh pernah ada kasus tersangka membuang barang bukti di jalan dalam kondisi hujan saat akan ditangkap. Narkotika yang tergerus air hujan tersebut pada akhirnya tidak dapat dijadikan sebagai barang bukti karena telah musnah.

c. Peredaran narkotika dikendalikan dari dalam LAPAS

Pengembangan kasus tindak pidana narkotika dari penangkapan tersangka terungkap bahwa proses peredaran narkotika dikendalikan oleh para narapidana yang masih berada di dalam Lapas. Hal ini menyulitkan penyidik untuk mengungkap kasus lebih lanjut, karena keterbatasan akses dari penyidik untuk masuk ke dalam Lapas.

d. Para pelaku tindak pidana narkotika saling melindungi satu sama lain

Dalam tindak pidana narkotika, para pelaku saling tertutup satu sama lain dan saling melndungi. Apalagi antara penjual, pembeli, kurir dan semua yang terlibat dalam tndak pidana narkotika tidak saling kenal. Hal ini dapat 
menghambat kerja penyidik dalam melakukan pengembangan kasus dan mengungkap tindak pidana narkotika.

\section{PENUTUP}

\section{Kesimpulan}

Penegakan hukum tindak pidana narkotika di wilayah hukum Polres Semarang pada tahap penyidikan dilaksanakan berdasarkan ketentuan KUHAP, Perkap Polri Nomor 14 Tahun 2012, dan UU Nomor 35 Tahun 2009. Penegakan hukum dilaksanakan melalui tahap penyelidikan yang berfungsi untuk mengetahui tindak pidana yang terjadi yang kemudian membuat berita acara serta laporan sebagai dasar permulaan penyidikan. Dalam pelaksanaan penyidikan tindak pidana narkotika, diupaya semaksimal mungkin untuk pengembangan kasus guna mengungkap jaringan peredaran narkotika di wilayah hukum Polres Semarang

\section{Saran}

Perlu adanya koordinasi dengan pihak-pihak terkait khususnya Lapas untuk mengungkap tindak pidana narkotika yang dikendalikan dari dalam LAPAS, Hendaknya pihak kepolisian melakukan sosialisasi terhadap masyarakat secara rutin untuk meningkatkan kesadaran hukum masyarakat untuk ikut berperan aktif dalam upaya pencegahan dan pemberantasan tindak pidana narkotika. 


\section{DAFTAR PUSTAKA}

\section{A. Buku}

Andi Hamzah, 2005, Hukum Acara Pidana Indonesia, Sinar Grafika, Jakarta.

AR. Sujono dan Bony Daniel, 2011, Komentar dan Pembahasan Undang-Undang Nomor 35 Tahun 2009 tentang Narkotika, Sinar Grafika, Jakarta.

Barda Nawawi Arief, 2006, Reformasi Sistem Peradilan (Sistem Penegakan Hukum) di Indonesia, Badan Penerbit UNDIP, Semarang.

Gatot Supramono, 2007, Hukum Narkoba Indonesia, Jakarta: Djambatan.

Hari Sasangka, 2003, Narkotika dan Psikotropika dalam Hukum Pidana, Mandar Maju, Bandung.

Hartono, 2010, Penyidikan dan Penegakan Hukum Pidana melalui Pendekatan Hukum Progresif, Sinar Grafika, Jakarta.

Moeljatno, 2008, Asas-asas Hukum Pidana, Rineka Cipta, Jakarta.

Munif Fuady, 2003, Aliran Hukum Kritis, Paradigma Ketidakberdayaan Hukum, Citra Aditya Bakti, Bandung.

M. Yahya Harahap, 2007, Pembahasan Permasalahan dan Penerapan KUHAP Penyidikan dan Penuntutan, Sinar Grafika, Jakarta.

P.A.F Lamintang, 1994, Kitab Undang-Undang Hukum Acara Pidana dengan Pembahasan secara Yuridis menurut Yurisprudensi dan Ilmu Pengetahuan Hukum Pidana, Sinar Baru, Bandung.

Ratna Nurul Alfiah, 1986, Praperadilan dan Ruang Lingkupnya, Akademika Pressindo, Jakarta.

Ronny Hanitijo Soemitro, 1988, Metode Penelitian Hukum dan Jurimetri, Ghalia Indonesia, Jakarta, 1988.

Soedarto, 1986, Kapita Selekta Hukum Pidana, Alumni, Bandung. 
Soedjono Dirdjosisworo, 2006, Narkoba dan Peradlannya di Indonesia, O.C Kaligis\&Assocates, Jakarta.

Soerjono Soekanto, 2008, Faktor-Faktor Yang Mempengaruhi Penegakan Hukum, PT. Raja Grafindo Persada , Jakarta.

Soesilo Yuwono, 1992, Penyelewengan Perkara Pidana berdasar $K U H P$, Alumni, Bandung.

Wirjono Prodjodikoro, 2003, Tindak-Tindak Pidana Tertentu di Indonesia, PT. Refika Aditama, Bandung.

\section{B. Perundang - Undangan}

Undang-Undang Dasar Negara Republik Indonesia Tahun 1945.

Undang-Undang Nomor 6 Tahun 2011 tentang Keimigrasian.

Undang-Undang Nomor 8 Tahun 1981 tentang Kitab Undang-undang Hukum Acara Pidana.

Kitab Undang-Undang Hukum Acara Pidana

Undang-Undang Nomor 2 Tahun 2002 tentang Kepolisian Negara Republik Indonesia.

Undang-Undang Nomor 29 Tahun 2004 tentang Praktek Kedokteran.

Undang-Undang Nomor 35 Tahun 2009 tentang Narkotika.

Undang-Undang Nomor 36 Tahun 2009 tentang Kesehatan.

Peraturan Kepala Kepolisian Republik Indonesia Nomor 14 Tahun 2012 tentang Manajemen Penyidikan Tindak Pidana 